\section{Synthesis of $C$-Glycopeptides via Free Radical Addition of Glycosyl Bromides to Dehydroalanine Derivatives **}

\author{
By Horst Kessler*, Valentin Wittmann, Matthias Köck, \\ and Matthias Kottenhahn
}

\section{Dedicated to Professor Ernst Bayer} on the occasion of his 65 th birthday

Glycoproteins are widely distributed in living organisms and their carbohydrate part plays a fundamental role in many processes of molecular recognition. ${ }^{[1,2]}$ The oligosaccharide side chain influences the conformation and solubility of proteins and can prohibit proteolytic cleavage. ${ }^{[3]}$ In most cases the sugar residues form an $N$-glycosidic bond to asparagine or an $O$-glycosidic bond to hydroxy-containing amino acids. Unusual and more stable linkages between carbohydrates and peptides are important for an understanding of the mutual interactions between both moieties.

We now report the facile synthesis of $C$-glycopeptides via free radicals according to the tin-hydride procedure of Giese et al. ${ }^{[4]}$ This new class of compounds ${ }^{[5]}$ is formally derived

[*] Prof. Dr. H. Kessler, Dipl.-Chem. V. Wittmann, Dipl.-Chem. M. Köck, Dr. M. Kottenhahn.

Organisch-chemisches Institut der Technischen Universität München Lichtenbergstrasse 4, D-W-8046 Garching (FRG)

[**] This work was supported by the Fonds der Chemischen Industrie and the Deutsche Forschungsgemeinschaft. V. W., M. K., and M. K. thank the Fonds der Chemischen Industrie for doctoral fellowships. reagents were mixed synchronously after they had been warmed to the reaction temperature. The sugars dehalogenated at $\mathrm{C} 1$ could be isolated as side products. Slow addition of a solution of $\mathrm{Bu}_{3} \mathrm{SnH}$ and $\mathrm{AIBN}$ in toluene to the reaction mixture resulted in reduced yields. As expected, ${ }^{[9]}$ the products are exclusively $(>97 \%) \alpha$-configurated at the "anomeric center" in the case of the monosaccharides 1 and 2. Only small amounts of $\beta$ - $C$-glycosides were formed when lactosyl bromide (3) was used $(12 \%$ when reacting with 4 , $4 \%$ with 5 ). In contrast to the high diastereoselectivity at the sugar, the hydrogen atom transfer to $\mathrm{C} 2$ of the amino acid yields mixtures of epimers. The diastereomeric ratios vary depending on the protecting group at the $N$-terminus of the amino acid. The best selectivity (3.8:1 in favor of the (2S)epimer) is obtained with Boc- $\triangle$ Ala-OBzl (6). The epimeric mixtures can be separated by HPLC. After the removal of the urethane group, gram-scale separation is possible by chromatography on a silica gel column.

To examine the possiblity of higher distereoselectivity through chirality in the dehydroamino acid building block, the enantiomeric dipeptides 7 and $\mathbf{8}$, as well as the tripeptide 9, were used. In all cases, even lower selectivity was observed (Table 1). In addition, the use of $\alpha, \beta$-unsaturated carbamides results in lower chemical yields. For electronic reasons, ${ }^{[10]}$ addition to a second dehydroalanine unit occurs (e.g., with Fmoc- $\triangle$ Ala-D-Phe-OBzl (8) a single diastereomer of $21^{[11]}$ is 
Table 1. Results of free-radical addition of glycosyl bromides 1-3 to dehydroalanine derivatives 4-9 according to Scheme 1. Abbreviations: Fmoc $=9$-fluorenylmethoxycarbonyl, $\mathrm{Z}=$ benzyloxycarbonyl, Boc $=$ tert-butyloxycarbonyl, $\triangle \mathrm{Ala}=$ dehydroalanine, TA-gal $=C$ - $(2,3,4,6$-tetra- $O$-acetyl-D-galactopyranosyl)- $\alpha(\mathbf{1} \rightarrow 3)$, TA-glc $=C$ - $(2,3,4,6$-tetra- $O$-acetyl-D-glucopyranosyl $)-\alpha(1 \rightarrow 3)$, HA-lac $=C$ - $\left(2,3,6,2^{\prime}, 3^{\prime}, 4^{\prime}, 6^{\prime}\right.$-hepta- $O$-acetyl-D-lactosyl)- $\alpha(1 \rightarrow 3)$.

\begin{tabular}{|c|c|c|c|c|c|c|}
\hline Bromide & Dehydroalanine Derivative & & Product [a] & & Yield $[\mathrm{b}]$ & $S: R[\mathrm{c}]$ \\
\hline 1 & Fmoc- $\triangle \mathrm{Ala}-\mathrm{OBz} \mathbf{l}$ & 4 & Fmoc-Ala(TA-gal)-OBzl & $(S)-10 /(R)-10$ & $65 \%$ & $2.5: 1$ \\
\hline 1 & $\mathrm{Z}-\Delta$ Ala-OBzl & 5 & Z-Ala(TA-gal)-OBzl & $(S)-11 /(R)-11$ & $60 \%$ & $2.4: 1$ \\
\hline 1 & Boc- $\triangle \mathrm{Ala}-\mathrm{OBzl}$ & 6 & Boc-Ala(TA-gal)-OBzl & $(S)-12 /(R)-12$ & $61 \%$ & $3.8: 1$ \\
\hline 2 & Fmoc- $\Delta$ Ala-OBzl & 4 & Fmoc-Ala(TA-glc)-OBzl & $(S)-13 /(R)-13$ & $73 \%$ & $2.6: 1$ \\
\hline 2 & $\mathrm{Z}-\triangle \mathrm{Ala}-\mathrm{OBzl}$ & 5 & Z-Ala(TA-glc)-OBzl & $(S)-14 /(R)-14$ & $55 \%$ & $2.3: 1$ \\
\hline 2 & $\mathrm{Boc}-\Delta \mathrm{Ala}-\mathrm{OBzl}$ & 6 & Boc-Ala(TA-glc)-OBzl & $(S)-15 /(R)-15$ & $65 \%$ & $3.8: 1$ \\
\hline 3 & Fmoc- $\triangle \mathrm{Ala}-\mathrm{OBz}$ & 4 & Fmoc-Ala(HA-lac)-OBzl & $(S)-16 /(R)-16$ & $55 \%$ & $(1.9: 1)$ \\
\hline 3 & Z- $\Delta$ Ala-OBzl & 5 & Z-Ala(HA-lac)-OBzl & $(S)-17 /(R)-17$ & $13 \%$ & $(3.2: 1)$ \\
\hline 1 & Fmoc- $\triangle$ Ala-Phe-OBzl & 7 & Fmoc-Ala(Ta-gal)-Phe-OBzl & $(S)-18 /(R)-18$ & $45 \%$ & $1.6: 1$ \\
\hline 1 & Fmoc- $\triangle \mathrm{Ala}-\mathrm{D}-\mathrm{Phe}-\mathrm{OBzl}$ & 8 & Fmoc-Ala(TA-gal)-D-Phe-OBzl & $(S)-19 /(R)-19$ & $23 \%$ & $\geq 2.0: 1$ \\
\hline 1 & Z-Pro- $\triangle$ Ala-Ala-OBzl & 9 & Z-Pro-Ala(TA-gal)-Ala-OBzl & $(S)-20 /(R)-20$ & $40 \%$ & $1.0: 1$ \\
\hline
\end{tabular}

[a] $(S)$ and $(R)$ correspond to the configuration at $\mathrm{C} 2$ of the glycosidized amino acid. The products were characterized by ${ }^{1} \mathrm{H}$ and ${ }^{13} \mathrm{C}$ NMR spectroscopy and FAB-MS. $[b]$ Overall yields of the $\alpha$ anomers after chromatography on silica gel. With the exception of two cases $(12 \%$ for $16,4 \%$ for 17$)$, no $\beta$ anomer could be detected (limit of detection $<3 \%$ ). [c] Isomeric ratios were determined by integration of corresponding signals in the ${ }^{1} \mathrm{H}$ NMR spectra or the HPLC chromatograms. The configuration at $\mathrm{C} 2$ was not assigned for compounds 16 and 17 (see text).

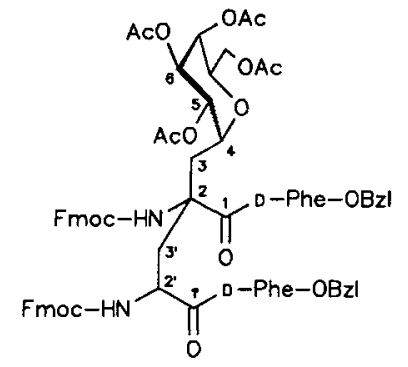

21

obtained in $53 \%$ yield). The higher stereoselectivity can be understood by the principle of double stereodifferentiation. ${ }^{[12]}$

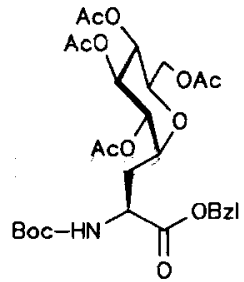

$(S)-15$

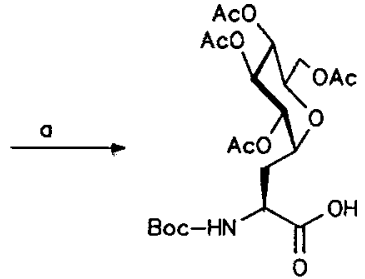

22

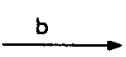<smiles>CC(C)(C)OC(=O)N[C@@H](C(=O)O[Na])C(O)C1OC(O)C2OC1C(O)C2O</smiles>

23

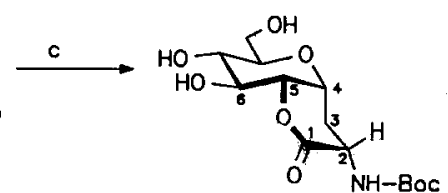

24
Scheme 2. Typical reaction sequence illustrated for the synthesis of compound 24. The lactones 25 and 26 were obtained analogously from coumpounds $(R)-15$ and $(S)-12$, respectively. a) $\mathrm{H}_{2}, 10 \% \mathrm{Pd}-\mathrm{C}, \mathrm{MeOH}$, room temperature, $1 \mathrm{~h}$; b) $\mathrm{NH}_{3}, \mathrm{MeOH}$, room temperature, $14 \mathrm{~h}$; c) $N$-ethyl- $N^{\prime}-\left(N^{\prime \prime}, N^{\prime \prime}\right.$-dimethylaminopropyl)carbodiimide (EDCI), 1-hydroxybenzotriazole (HOBT), dimethylacetamide (DMA)/THF $(1: 1)$, room temperature, $14 \mathrm{~h}$. Quantitative yields were obtained for all three reaction steps.
The determination of the absolute configuration at $\mathrm{C} 2$ of the amino acids was carried out by NMR spectroscopy of the conformationally restricted lactones 24,25 , and 26 (see Scheme 3) and subsequent refinement by molecular dynamics calculations. The lactones were prepared in three steps starting from the corresponding $C$-glycosyl alanine derivatives $(S)$-15, $(R)-15$, and (S)-12 (Scheme 2). The assignment of proton and carbon atoms was performed by COSY and HMQC ${ }^{[13]}$ spectra. A mixture of $\left[\mathrm{D}_{6}\right] \mathrm{DMSO} / \mathrm{CDCl}_{3}$ was used in the ratio $1: 2$ for the lactones 24 and 26 but $1: 1.4$ for lactone 25. Pure [ $\mathrm{D}_{6}$ ] DMSO could not be used because of overlap in the ${ }^{1} \mathrm{HNMR}$ spectrum. An HMBCS270 experiment ${ }^{[14]}$ confirmed the cyclization to the $\delta$-lactone $\left({ }^{3} J_{\mathrm{C} 1, \mathrm{H} 5}\right) .{ }^{1} \mathrm{H},{ }^{1} \mathrm{H}$ coupling constants were extracted from $1 \mathrm{D}$ spectra after apodization. The interproton distances were obtained from $500 \mathrm{MHz}$ ROESY spectra ${ }^{[15]}$ with a mixing time of $150 \mathrm{~ms}$. Using these data we could assign both diastereotopic protons at $\mathrm{C} 3$. A qualitative inspection of the

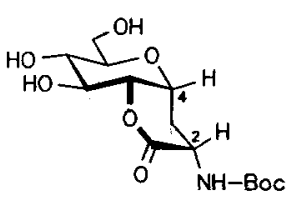

24

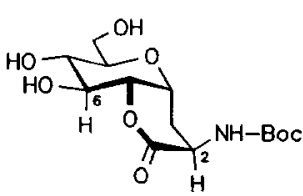

25

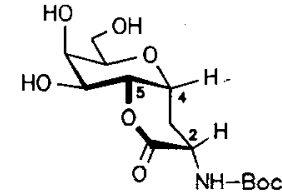

26

Scheme 3. Formulas of the lactones $24-26$ synthesized to assign the absolute configuration at $\mathrm{C} 2$.

ROESY spectra allows for discrimination between lactones 24 and 25; a cross peak is observed between $\mathrm{H} 2$ and $\mathrm{H} 4$ for 24 but between $\mathrm{H} 2$ and $\mathrm{H} 6$ for 25 . This proves the assignment of the absolute configuration $(2 S)$ for $\mathbf{2 4}$ but $(2 R)$ for 25, as shown in Figure 1.

To refine the structures, restrained MD simulations (Discover ${ }^{[16]}$ ) were performed by using the interproton distances (25 distances for compound $\mathbf{2 4}$ and 16 distances for 25). ${ }^{[17]}$ The calculated structures (Fig. 1) are in agreement with all measured distances and coupling constants (Table 2). The simulation was then continued for 300 ps without restraints 


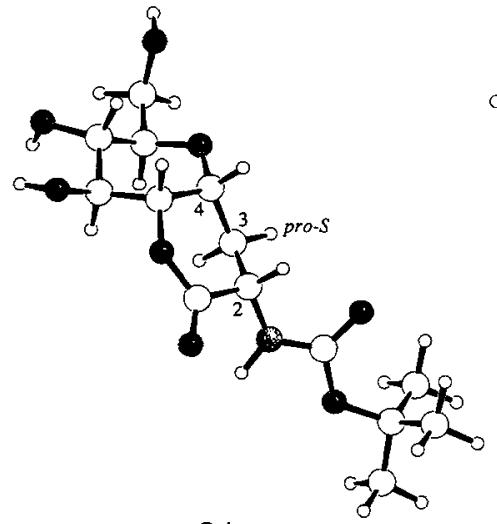

24

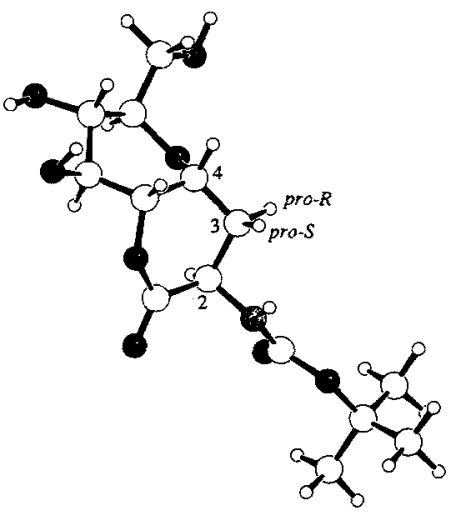

25
Fig. 1. MD structures of the lactones 24 and $\mathbf{2 5}$. Oxygen atoms are filled, and nitrogen atoms are stippled.

and exhibited the stability of the obtained structures. To prove the configuration at $\mathrm{C} 2$, a calculation under identical conditions but with exchanged starting configurations was performed. As expected, considerable deviations from the interproton distances obtained from NMR spectroscopy were observed. In lactone 26, which stems from the galactose series, strong ROEs from $\mathrm{H} 2$ to $\mathrm{H} 4$ and $\mathrm{H} 5$ are observed, proving the $(2 S)$ configuration as in 24 . Again, additional evidence is provided by the ${ }^{1} \mathrm{H},{ }^{1} \mathrm{H}$ coupling constants (Table 2). The absolute configurations of the lactosyl compounds 16 and 17 were not determined but assumed to be the $(2 S)$ epimers from analogy with the main products. Transformation of the $C$-glycosides $(S)-12$ and $(S)-15$ into $(S)$-10, $(S)-11,(S)-18,(S)-19$, and $(S)-13,(S)-14$, respectively, indicates the natural $(2 S)$ configuration at the amino acids for all other major products.

Table 2. Selected ${ }^{1} \mathrm{H},{ }^{1} \mathrm{H}$ coupling constants for compounds 24-26.

\begin{tabular}{lllll}
\hline${ }^{3} J(\mathrm{H}, \mathrm{H})$ & $2,3($ pro- $R)$ & $2,3($ pro- $S)$ & $4,3($ pro- $R)$ & $4,3($ pro- $S)$ \\
\hline $\mathbf{2 4}$ & 13.1 & 6.5 & 9.4 & 6.6 \\
$\mathbf{2 5}$ & 6.6 & 12.1 & 4.3 & 3.7 \\
$\mathbf{2 6}$ & 12.7 & 7.6 & 5.7 & 8.1 \\
\hline
\end{tabular}

The procedure described here yields nonnatural $C$-glycosyl amino acids and $C$-glycosyl peptides in one step with high diastereoselectivity at the anomeric center, from readily available starting materials. The products exhibit high chemical stability, are suitable as potential glycosidase inhibitors, and provide a method to improve pharmaco kinetic properties of peptides.

\section{General procedure}

The protected dehydroamino acid is dissolved in dry toluene (about $0.1 \mathrm{M}$ ) together with 1.2-2 equivalents of glycosyl bromide and warmed to approximately $60^{\circ} \mathrm{C} . \mathrm{Bu}_{3} \mathrm{SnH}(1.2-2$ equiv) and catalytic amounts of AIBN are added under nitrogen or argon.

After completion of the reaction (monitored by TLC), the solvent is evaporated, the residue dissolved in acetonitrile and extracted three to five times with hexane to remove the tin compounds. The acetonitrile is evaporated, and the remaining oil purified by silica gel chromatography. The products are distereomeric mixtures of $\mathrm{L}$ - and $\mathrm{D}$-amino acids.
CAS Registry numbers:

1, 3068-32-4; 2, 572-09-8; 3, 4753-07-5; 4, 141665-73-8;5, 59524-07-1; 6, 94882$75-4 ; 7,141665-74-9 ; 8,141665-75-0 ; 9,141665-76-1 ;(S)-10,141665-77-2 ;(R)$ $10,141665-91-0 ;(S)-11,141665-78-3 ;(R)-11,141665-92-1 ;(S)-12,141665-79-$ 4; $(R)-12,141665-93-2$; (S)-13, 141684-32-4; $(R)-13,141645-94-3$; (S)-14, $141665-80-7 ;(R)-14,141665-95-4 ;(S)-15,141665-81-8 ;(R)-15,141665-96-5$; $(S)-16,141684-33-5 ;(R)-16,141665-97-6 ;(S)-17,141665-82-9 ;(R)-17,141665-$ 98-7; (S)-18, 141665-83-0; $(R)-18,141725-28-2 ;(S)-19,141725-27-1 ;(R)-19$, 141725-29-3; (S)-20, 141665-84-1; (R)-20, 141725-30-6; 21, 141665-85-2; 22, $141665-86-3 ; 23,141665-87-4 ; 24,141665-88-5 ; 25,141665-89-6 ; 26,141665-$ $90-9$.

[1] J. Montreuil in Comprehensive Biachemistry, Vol. 19 BII (Eds.: A. Neuberger, L. L. van Deenen), Elsevier, Amsterdam, 1982, p. 1-189.

[2] N. Sharon, H. Lis, Chem. Eng. News 1981, 59 (13), $21-44$.

[3] a) K. Olden, J. B. Parent, S. L. White, Biochem. Biophys. Acta 1982, 650, 209-232; b) K. Olden, B. A. Bernard, M. J. Humphries, T.-K. Yeo, K.-T. Yeo, S. L. White, S. A. Newton, H. C. Bauer, J. B. Parent, Trends Biochem. Sci. 1985, 10, 78-82.

[4] a) B. Giese, J. Dupuis, Angew. Chem. 1983, 95, 633-634; Angew. Chem. Int. Ed. Engl. 1983, 22, 622-623; b) B. Giese, J. Dupuis, M. Leising, M. Nix, H. J. Lindner, Carbohydr. Res. 1987, 171, 329-341; c) B. Giese, T. Linker, R. Muhn, Tetrahedron 1989, 45, 935-940.

[5] M. Kottenhahn, Dissertation, Universität Frankfurt, 1989. The synthesis of similar compounds has been described recently: G. Simchen, E. Pürkner, Synthesis 1990, 525-527; L. Colombo, G. Casiraghi, A. Pittalis, G. Rassu, J. Org. Chem. 1991, 56, 3897-3900.

[6] M. J. Miller, J. Org. Chem. 1980, 45, 3131-3132.

[7] V. Wittmann, Diplom thesis, Universität Frankfurt, 1990.

[8] For example $(S)$-15: $[\alpha]_{D}^{22}=50.6\left(c=1, \mathrm{CDCl}_{3}\right)$; FAB-MS: $m / z 610$ $\left(M+\mathrm{H}^{\oplus}\right) ;{ }^{1} \mathrm{H}$ NMR $\left(250 \mathrm{MHz}, \mathrm{CDCl}_{3}, 300 \mathrm{~K}, \mathrm{TMS}\right): \delta=7.42-7.32(\mathrm{~m}$, $\left.5 \mathrm{H}, \mathrm{C}_{6} \mathrm{H}_{5}\right), 5.35(\mathrm{~d}, 1 \mathrm{H}, \mathrm{NH}), 5.20(\mathrm{dd}, 1 \mathrm{H}, \mathrm{H}-6), 5.30-5.14(\mathrm{~m}, 2 \mathrm{H}$, $\mathrm{CH}_{2}-\mathrm{Ph}$ ), 5.02 (dd, $1 \mathrm{H}, \mathrm{H}-5$ ), 4.96 (dd, $\left.1 \mathrm{H}, \mathrm{H}-7\right), 4.46$ (m, $\left.1 \mathrm{H}, \mathrm{H}-2\right), 4.35$ (ddd, $1 \mathrm{H}, \mathrm{H}-4$ ), 4.21 (dd, $1 \mathrm{H}, \mathrm{H}-9 \mathrm{~b}$ ), 3.95 (dd, $1 \mathrm{H}, \mathrm{H}-9 \mathrm{a}$ ), 3.85 (ddd, $1 \mathrm{H}$, H-8), 2.24 (ddd, $1 \mathrm{H}, \mathrm{H}-3 \mathrm{~b}$ ), 2.08 (ddd, $1 \mathrm{H}, \mathrm{H}-3 \mathrm{a}$ ), 2.10-2.00 (4 s, $12 \mathrm{H}$, OAc) $1.42(\mathrm{~s}, 9 \mathrm{H}, \mathrm{BOc}) ; J(\mathrm{NH}, 2)=7.2, J(4,5)=5.3, J(5,6)=8.7$, $J(6,7)=7.4, \quad J(7,8)=8.6, \quad J(8,9 \mathrm{a})=2.7, \quad J(8,9 \mathrm{~b})=4.8, \quad J(9 \mathrm{a}, 9 \mathrm{~b})=$ $12.2 \mathrm{~Hz} ;{ }^{13} \mathrm{C} \operatorname{NMR}\left(62.5 \mathrm{mHz}, \mathrm{CDCl}_{3}, 300 \mathrm{~K}\right): \delta=171.4,170.6,169.8$, 169.4, 169.3, $154.9(\mathrm{C}=\mathrm{O}), 135.0,128.6,128.5,128.3\left(\mathrm{C}_{6} \mathrm{H}_{5}\right), 80.1\left(\mathrm{CMe}_{3}\right)$, 69.9 (C-8), 69.8 (C-6), 69.5 (C-5), $68.7(\mathrm{C}-4), 67.9(\mathrm{C}-7), 67.3\left(\mathrm{CH}_{2}-\mathrm{Ph}\right)$, $61.5(\mathrm{C}-9), 50.5(\mathrm{C}-2), 28.2\left(\mathrm{C}-3\right.$ and $\left.\mathrm{C}\left(\mathrm{CH}_{3}\right)_{3}\right), 20.6\left(4(\mathrm{CO}) \mathrm{CH}{ }_{3}\right)$.

[9] B. Giese, Angew. Chem. 1989, 101,993-1004; Angew. Chem. Int. Ed. Engl. 1989, 28, 969-980.

[10] a) B. Giese, Radicals in Organic Synthesis: Formation of Carbon-Carbon Bonds, 1st ed., Pergamon, Oxford, 1986, p. 7-10; b) Angew. Chem. 1983, 95, 771-782; Angew. Chem. Int. Ed. Engl. 1983, 22, 753-764.

[11] 21: FAB-MS: $m / z 1425.5\left(M+\mathrm{H}^{\oplus}\right)$; ${ }^{1} \mathrm{H}$ NMR $\left(500 \mathrm{MHz}, \mathrm{CDCl}_{3}, 300 \mathrm{~K}\right.$, TMS): $\delta=8.12(\mathrm{~d}, 1 \mathrm{H}$, Phe-NH), $7.70-7.10(\mathrm{~m}, 36 \mathrm{H}$, arenes $), 7.05(\mathrm{~d}$, $1 \mathrm{H}$, Phe-NH), 6.97 (s, $1 \mathrm{H}, \mathrm{NH}), 5.73(\mathrm{~d}, 1 \mathrm{H}, \mathrm{NH}), 5.23-5.13(\mathrm{~m}, 4 \mathrm{H}, 2$ $\mathrm{CH}_{2}-\mathrm{Ph}$ ), 5.09 (dd, $1 \mathrm{H}, \mathrm{H}-7$ ), 5.04 (dd, $1 \mathrm{H}, \mathrm{H}-5$ ), 4.93 (dd, $1 \mathrm{H}, \mathrm{H}-6$ ) , 4.90, 4.64 (each ddd, $2 \mathrm{H}$, each Phe-H- $\alpha$ ), 4.33, 3.85 (each in, $2 \mathrm{H}, \mathrm{Fmoc}-\mathrm{CH}_{2}$ ), 4,27, 3.92 (each $\mathrm{m}, 2 \mathrm{H}$, Fmoc- $\mathrm{CH}_{2}$ ) 4.25 (ddd, $\left.1 \mathrm{H}, \mathrm{H}-4\right), 4.12$ (dd, $1 \mathrm{H}$, $\mathrm{H}-9 \mathrm{~b}$ ), 4.06 (ddd, $1 \mathrm{H}, \mathrm{H}-2$ ') , 4.05, 3.94 (each m, $2 \mathrm{H}$, each Fmoc-H-9), 3.74 (dd, $1 \mathrm{H}, \mathrm{H}-9 \mathrm{a}$ ), 3.30 (ddd, $1 \mathrm{H}, \mathrm{H}-8$ ), $3.10,2.91$ (each dd, $2 \mathrm{H}$, Phe-H- $\beta$ ), 3.08, 3.00 (each dd, $2 \mathrm{H}$, Phe-H- $\beta$ ), 2.62 (dd, $1 \mathrm{H}, \mathrm{H}-3$ 'b), 2.42 (dd, $1 \mathrm{H}$, H-3b), 2.30 (dd, 1 H, H-3'a), 1.94 (dd, 1 H, H-3a), 2.07-1.94 (4 s, 12 H, OAc); ${ }^{3} \mathrm{C}$ NMR $\left(125 \mathrm{MHz}, \mathrm{CDCl}_{3}, 300 \mathrm{~K}\right): \delta=172.5,172.3,172.2$, $170.7,169.9,169.7,169.6,169.5,155.9,155.4(\mathrm{C}=\mathrm{O}), 143.8-119.8$ (arenes), 68.5 (C-8), $67.8\left(\mathrm{C}-4, \mathrm{C}-5, \mathrm{CH}_{2}-\mathrm{Ph}\right), 67.3\left(\mathrm{C}-6, \mathrm{CH}_{2}-\mathrm{Ph}\right), 67.2(\mathrm{C}-7)$, 67.1 (2 Fmoc-CH ${ }_{2}$ ), 61.2 (C-9), 60.8 (C-2), 54.9, 53.9 (each Phe-C- $\alpha$ ), 51.2 (C-2'), 47.0, 46.8 (each Fmoc-C-9), 40.8 (C-3'), 37.4, 36.7 (each Phe-C- $\beta$ ), $32.5(\mathrm{C}-3), 20.9-20.6\left(4(\mathrm{CO}) \mathrm{CH}_{3}\right)$.

[12] S. Masamune, W. Choy, J. S. Petersen, L. R. Sita, Angew. Chem. 1985, 97 , 1-31; Angew. Chem. Int. Ed. Engl. 1985, 24, 1-30.

[13] A. Bax, S. Subramanian, J. Magn. Reson. 1986, 67, 565-569.

[14] H. Kessler, P. Schmieder, M. Köck, M. Kurz, J. Magn. Reson. 1990, 88, 615-618.

[15] a) A. A. Bothner-By, R. L. Stevens, J. Lee, C. D. Warren, R. W. Jeanloz, J. Am. Chem. Soc. 1984, 106, 811-813; b) H. Kessler, C. Griesinger, R. Kerssebaum, K. Wagner, R. R. Ernst, ibid. 1987, 109, 607-609; c) C. Griesinger, R. R. Ernst, J. Magn. Reson. 1987, 75, 261-271.

[16] A. T. Hagler in The Peptides, Vol. 7 (Eds.: S. Udenfriend, J. Meienhofer, V. Hruby), Academic Press, Orlando, Fl, USA, 1985, p. 214-296.

[17] Restrained MD simulations in vacuum were performed over $150 \mathrm{ps}$. The time step for the integration of Newton's equations of motion was $1.0 \mathrm{fs}$. The starting structures were built interactively with INSIGHT. To take into account errors in the ROESY cross-peak intensities and for the interconversion into distanes, $5 \%$ were subtracted from the lower and added to the upper bounds. The simulations were performed for $5 \mathrm{ps}$ at $1000 \mathrm{~K}$, then for 10 ps at $500 \mathrm{~K}$, and finally for an additional 135 ps at $300 \mathrm{~K}$. Only the last 100 ps were used for analysis. 